\title{
Comparative Study of Four Different Brands of Ranitidine Available in Karachi
}

\author{
Safila Naveed ${ }^{*}$, Huma Dilshad and Lailoona Jaweed
}

Faculty of Pharmacy, Jinnah University for Women, Karachi, Pakistan

\begin{abstract}
Ranitidine is used in peptic ulcer therapy and available as several brands in the market which makes it difficult to select the safe, effective and economic one. The aim of this study is to establish similarity among the different brands of ranitidine $\mathrm{HCl}$ tablets available in local market of Karachi, Pakistan. Four different brands of (150 mg) were selected for the study. Six quality control parameters: weight variation test, hardness test, thickness, friability, disintegration test and dissolution test were carried out specified by USP. Result revealed that all brands comply within limits for hardness, weight variation, thickness, friability, disintegration and dissolution. Disintegration time for all brands was within 15 minutes complying with the USP commendation. All brands showed Q-value more than $80 \%$ within 45 minutes. The present findings suggest that almost all the brands of ranitidine $\mathrm{HCl}$ that are available in Karachi meet the USP specification for quality control analysis and are interchangeable.
\end{abstract}

Keywords: Ranitidine $\mathrm{HCl}$; Comparative study; Pharmaceutical formulations

\section{Introduction}

Comparative analysis is carried out to check, compare and evaluate the quality standards of commercially available local pharmaceutical brands of tablets with that of multinational pharmaceutical brands in Pakistan as prescribed by B.P. \& U.S.P. Local and Multinational brands of drugs were evaluated comparatively for their physical and chemical parameters [1]. It is said that marketed oral drugs will generally possess favorable physiochemical properties with respect to absorption, metabolism, distribution, and clearance [2].

Ranitidine is Figure 1, an $\mathrm{H}_{2}$ receptor antagonist that inhibits the acid production from stomach, it is used in the treatment of duodenal and gastric ulcer caused by helicobacter pylori infection, and for the treatment of gastrointestinal reflux disease [3]. It inhibits the secretion of acid which is stimulated by pentagastrin (an-enzyme), meal and histamine $[3,4]$. Histamine is a natural chemical that stimulates the stomach cells to produce acid [5]. Ranitidine is a new histamine $\mathrm{H}_{2}$ receptor antagonist which does not contain imidazole group unlike cimetidine. On a weight basis, ranitidine is 4 to 10 times more potent than cimetidine in inhibiting stimulated gastric acid secretion in humans [4,6]. Ranitidine has a greater selectivity of action than cimetidine so avoiding certain unwanted effects such as interference with enzymatic degradation of a wide range of drugs metabolized by the liver [7]. Ranitidine acts by inhibiting parietal cell $\mathrm{H}_{2}$ receptor competitively and suppress the normal secretion of acid which is stimulated by meal [8]. It is accomplished by two mechanisms blocking of histamine released by ECL cells present in the stomach by parietal cell $\mathrm{H}_{2}$ receptor which in turns block the cascade of acid secretion

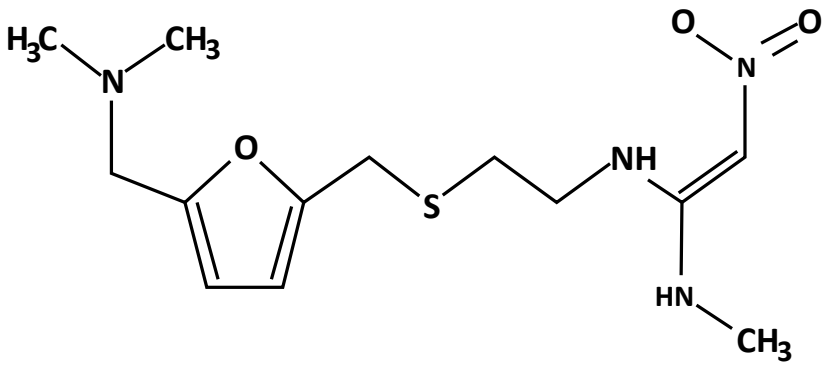

Figure 1: Ranitidine Molecular Structure $\left(\mathrm{C}_{13} \mathrm{H}_{22} \mathrm{~N}_{4} \mathrm{O}_{3} \mathrm{~S} . \mathrm{Hcl}\right)$. and secondly blocking the other factors like acetylcholine and gastrin (enzyme) which have reduce but effect on $\mathrm{H}_{2}$ receptors [6,9].

Like the $\mathrm{H}_{1}$-antihistamines, the $\mathrm{H}_{2}$ antagonists are inverse agonists rather than true receptor antagonists. The $\mathrm{H}_{2}$-antagonists offer numerous benefits over antacids, including prolong duration of action i.e. 6-10 hours as compare to 1-2 hours for other antacids greater and bears efficacy and ability to be used prophylactically before meals to minimize the possibility of heartburn after food intake [9] (Figure 1).

Ranitidine is widely used in short term treatment of duodenal ulcer and in the management of hypersecretory conditions $[4,10,11]$. The dose recommended by WHO for ranitidine is $150 \mathrm{mg}$ tablet containing ranitidine base, given as the hydrochloride salt $[4,11]$. Twice-daily treatment with ranitidine $150 \mathrm{mg}$ is a valuable therapy for GERD in a typical family practice setting and reduces the frequency and severity of symptoms within the first 24 to 48 hours of treatment [12]. Another study conducted in Oman showed that different brands of ranitidine

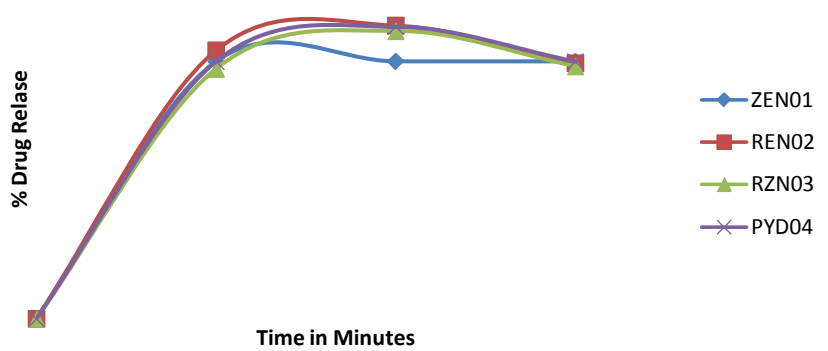

Figure 2: \%Drug Release of various brands Vs. Time.

${ }^{*}$ Corresponding author: Safila Naveed, Faculty of Pharmacy, Jinnah University for Women, Karachi, Pakistan, Tel: 009-21-366-324; E-mail: safila117@yahoo.com

Received April 21, 2014; Accepted May 27, 2014; Published May 30, 2014

Citation: Naveed S, Dilshad H, Jaweed L (2014) Comparative Study of Four Different Brands of Ranitidine Available in Karachi. Mod Chem appl 2: 125 doi:10.4172/2329-6798.1000125

Copyright: $\odot 2014$ Naveed S, et al. This is an open-access article distributed under the terms of the Creative Commons Attribution License, which permits unrestricted use, distribution, and reproduction in any medium, provided the original author and source are credited. 
available in market that pharmaceutical equivalent with a slight difference in manufacturing process [13].

The aim of the study is to evaluate equivalence of different ranitidine $\mathrm{HCl}$ tablets brands of available in Karachi. Comparison of the quality aspects of ranitidine will help for the selection of best brand of drug by the pharmacist or doctors. This study aims to provide the proof of safety, effectiveness of the drugs can be used.

\section{Methodology}

Test performed in order to conduct a comparative study between four different brands of active ranitidine, available in market of purchased and coded as ZAN01 (multinational brand taken as standard) and three local brands given serial no as REN02, RZN03, PYD04 and tested for following physiochemical parameters in order to conduct a comparative study among the brand leader of multinational company and other local company brands. Following test parameters are performed to evaluate the physicochemical parameters of available brands of ranitidine:

\section{Weight variation}

Variation in weight was checked on A.N.D Electronic Balance FX400. Weight variation between tablet with respect to dose and weight must be within BP limits. For which 20 tablets of each brand is selected randomly. In-process uniformity of weight is a test parameter which ensures evenness of dosage units through compression. The percentage weight variation from average tablet weight was calculated. In order to pass weight variation test, the tablet should be within the limits of the percentage deviation allowed by BP. Upper and lower control limit for weight variation is calculated as per following formula:

Upper control limit: Mean+3x Standard Deviation

Lower control limit: Mean- 3x Standard Deviation

And Maximum and minimum weight variation limit in percentage was calculated as per following formula:

Max wt. variation \%=(Maximum weight - Average weight $) /$ Average weight $\times 100$

Min wt. variation $\%=($ Average weight - Minimum Weight $) /$ Average weight $\times 100$

\section{Thickness}

The degree of compaction of 20 tablet of each brand is assessed by measuring the thickness of tablets, by using VERNIER CALIPER.

\section{Hardness}

This test is conducted on 10 tablets of each brand to determine the strength of tablet when applied mechanical stress. A tablet must be hard enough to endure stress. Hardness of all the brands is checked on $\mathrm{MH}-$ 1, Hardness Tester of Galvano Scientific. The hardness value of each tablet was evaluated and average value was calculated and compared.

\section{Friability}

Friability test has been performed on 10 tablets of each brand of ranitidine by subjecting to a uniform tumbling motion for specified period of time i.e. 25 rotation/minute for 4 minutes in FB-1004 CURIO Company and the weight loss is determined. Friability test is done to check if a tablet abrades during transportation by taking initial and final weight and determining the weight loss.

\section{Disintegration}

Disintegration Testing is one of the quality control test done to determine whether capsules or tablets are disintegrating within the approved time when placed in a fluid medium. Disintegration test for all brands s was done on CURRO MODEL NO DS-0702. A $900 \mathrm{ml}$ beaker was filled with distilled water and temperature was maintained at $37 \pm 2^{\circ} \mathrm{C}$. From each brand, 6 tablets of each brand were selected randomly and placed into the basket rack assembly and connected to the disintegration apparatus. The disintegration time for each brand is compared with the Pharmacopoeial limit specified by BP.

\section{Dissolution}

This test determines the amount of active ingredient released from oral solid dosage form, i.e. tablet or a capsule, using medium with known volume. Tablet dissolution was conducted on model no. GDT-7L of Galvano Scientific. It is carried out to determine the bioavailability of drug invitro dissolution tests were performed with the paddle apparatus I in $900 \mathrm{ml} 0.1 \mathrm{~N} \mathrm{HCL}$ dissolution media at $100 \mathrm{rpm}$ for 60 minutes. The tablets were placed in the vessels at the beginning of each test and the stopwatch was started simultaneously. In order to minimize evaporation vessels are covered during the run with plastic covers. The temperature in the vessels was maintained at $37 \pm 0.5^{\circ} \mathrm{C}$ throughout every dissolution run. Manually samples are removed using $5 \mathrm{ml}$ syringes fitted with stainless tubing to make certain reproducibility of the sampling site. Samples are filtered. In vitro dissolution testing parameters used for are described in Table below:

\section{Price variation study}

Per unit retail price of the different brands of Ranitidine $\mathrm{HCl}$ under study was noted and the average price of all brands compared.

\section{Statistical analysis}

Data were recorded coded and analyzed statistically using Microsoft Excel and various parameters are evaluated and compared (Tables 2 and 3).

\section{Results and Discussion}

Pakistan is one of the developing country that is striving for survival of its economy and cost of living is increasing day by day, in such a scenario people use to show un-affordability towards the use

\begin{tabular}{|l|l|}
\hline Parameter of Method & \\
\hline Apparatus & $\mathrm{I}$ \\
\hline Dissolution Medium & $0.1 \mathrm{~N} \mathrm{HCL}$ \\
\hline Analytical Instrument & UV-VIS Spectrometer \\
\hline Wavelength & $315 \mathrm{~nm}$ \\
\hline Agitation & $50 \mathrm{RPM}$ \\
\hline Degassing & Yes \\
\hline Volume & $900 \mathrm{ml}$ \\
\hline Temperature & $37^{\circ} \mathrm{C}$ \\
\hline Sampling Time & $0,15,30,45$, Minutes \\
\hline Tolerances & $\mathrm{NLT} 80 \%(\mathrm{Q})$ of the labeled amount in $45 \mathrm{~min}$ \\
\hline
\end{tabular}

Table 1: In vitro dissolution testing parameters.

\begin{tabular}{|l|l|l|l|l|}
\hline SNO & Serial No & Code No & Batch No & Price/10 Units PKR \\
\hline 1 & ZAN01 & 6520 & CZBBR & 88 \\
\hline 2 & REN02 & 47498 & RP026 & 59.45 \\
\hline 3 & RZN03 & 42567 & 1673 & 56 \\
\hline 4 & PYD04 & 42514 & 027 & 54 \\
\hline
\end{tabular}

Table 2: Label Information. 
Citation: Naveed S, Dilshad H, Jaweed L (2014) Comparative Study of Four Different Brands of Ranitidine Available in Karachi. Mod Chem appl 2: 125. doi:10.4172/2329-6798.1000125

Page 3 of 3

\begin{tabular}{|c|c|c|c|c|c|c|}
\hline SNO & Brand & Mean Weight \pm SD $\mathrm{mg}$ & Mean Thickness \pm SD $\mathrm{n} \mathrm{mm}$ & Mean Hardness \pm SD kg & Friability \pm SD in $\%$ & Disintegration in $\min$ \\
\hline 1 & ZEN01 & $303.2 \pm 2.16$ & $5.54 \pm 0.069$ & $5.33 \pm 0.4$ & $0 \%$ & $10 \mathrm{~min} 27 \mathrm{sec}$ \\
\hline 2 & REN02 & $216.2 \pm 5.42$ & $4.23 \pm 0.067$ & $4.48 \pm 0.26$ & $0 \%$ & $6 \min 6 \mathrm{sec}$ \\
\hline 3 & RZN03 & $211.9 \pm 2.45$ & $4.26 \pm 0.142$ & $7.4 \pm 0.4$ & $0 \%$ & $14 \min 35 \mathrm{sec}$ \\
\hline 4 & PYD04 & $257.4 \pm 5.8$ & $4.25 \pm 0.051$ & $4.01 \pm 0.244$ & $0 \%$ & $11 \mathrm{~min} 4 \mathrm{sec}$ \\
\hline
\end{tabular}

Table 3: Mean Weight, thickness, hardness, friability and disintegration of all available brands in Karachi.

of medicine. Here the diet used is usually spicy and other factors like stress is also available that leads to several acidity cases, since they are young. So in such circumstances use of drug like ranitidine becomes necessary to avoid the complications but here the cost of that medicine may affect the compliance level.

This study is based on the comparison of available ranitidine brands in market that are available for consumer use. Four brands of drug was taken that are coded accordingly, batch number and price are mentioned in Table 1 each brand taken was having $150 \mathrm{mg}$ of ranitidine.

Price variation of all the brands are checked and compared indicating a fact that all the local brands are less in price as compare to brand leader while having similar or better physicochemical property. Local brand has taken less time to dissolute and are having all other parameters similar to brand leader, but having low price than ZAN01, indicating the fact that they are physicochemical equivalent with brand leader having cost of Rs $88 / 10$ tablets.

All tablet contain $150 \mathrm{mg}$ active but are of different weight probably because of different excipients use for the manufacturing that are increasing the bulk or weight of the tablet, while others are avoiding this and are having weight less than $250 \mathrm{mg}$ having weight variation up to $7.5 \%$ while the brand leader falls in $5 \%$ range of deviation from average weight. The other point that should come under light is the disintegration time shown in Table 2, a local brand having serial no REN02 has the least disintegration time that is $6 \mathrm{~min}$ and $6 \mathrm{sec}$ as compare to the brand leader having disintegration time $10 \mathrm{~min} 27 \mathrm{sec}$, while one local brand of same cost has maximum dissolution time that is 14 minutes $35 \mathrm{sec}$.

All the brands having $\mathrm{Q}$ value within the limits that is not less than $80 \%$ as given in USP. Dissolution is measured as one of the most significant quality control tests performed on pharmaceutical dosage forms and is now emerging as a tool for calculating bioavailability. Figure 1 explains the \% dissolution of available brands at different time interval that are $0,15,30$, and 45 mintes, that are about $100 \%$ indicating the bioavailability of all the brands.

\section{Conclusion}

Hence it is concluded from above discussion that all the available brands in local market of Karachi Pakistan are having physicochemical parameters within the specified quality control range and can be interchange if found any non-compliance due to cost issue.

\section{References}

1. Imran M, ul Hassana N Shifa KM, Kishwar S, Humaira N, et al. (2011) Comparative in-vitro analysis of different available brands of paracetamol in Pakistan. Journal of Pharmacy Research4: 4399.

2. Wenlock MC, Austin RP, Barton P, Davis AM, Leeson PD (2003) A comparison of physiochemical property profiles of development and marketed oral drugs. J Med Chem 46: 1250-1256.

3. Sweetman SC (2009) Martindale: The complete drug reference. Pharmaceutica Press, London, UK.

4. Brogden RN, Carmine AA, Heel RC, Speight TM, Avery GS (1982) Ranitidine: a review of its pharmacology and therapeutic use in peptic ulcer disease and other allied diseases. Drugs 24: 267-303.

5. Davies RE (1951) The mechanism of hydrochloric acid production by the stomach. Biological Reviews 26: 87-120.

6. Waldum HL, Hauso O, Fossmark R (2013) The regulation of gastric acid secretion - clinical perspectives. ActaPhysiol (Oxf) 210: 239-256.

7. Walker MJ (2011) The major impacts of James Black's drug discoveries on medicine and pharmacology. Trends Pharmacol Sci 32: 183-188.

8. MössnerJ, Caca K (2005) Developments in the inhibition of gastric acid secretion. Eur J Clin Invest 35: 469-475.

9. Narayana B, Ashwini K (2010)Novel Reagent for the Spectrophotometric Determination of Ranitidine Hydrochloride. Eurasian J Anal Chem 5: 170-176.

10. Malfertheiner P, Chan FK, McColl KE (2009) Peptic ulcer disease. Lancet 374 1449-1461.

11. Kortejärvi $\mathrm{H}$, Yliperttula $\mathrm{M}$, Dressman JB, Junginger $\mathrm{HE}$, Midha $\mathrm{KK}$, et al (2005) Biowaiver monographs for immediate release solid oral dosage forms: ranitidine hydrochloride.J Pharm Sci 94: 1617-1625.

12. Al Talalwah N, Woodward S (2013) Gastro-oesophageal reflux. Part 2: medical treatment. Br J Nurs 22: 277-284.

13. Mullaicharam AR, Jehangir Ahmed JH, Halligudi N (2012) Evaluation of pharmaceutical equivalents of different brands of ranitidine tablets from multinational brands in Oman. International Journal of Nutrition, Pharmacology Neurological Diseases 2:40-44. 